\title{
Jødisk polemik mod kristne dogmer i middelalderen fra det første korstog i 1096 til uddrivelsen af jøderne fra Spanien i $1492^{1}$
}

\author{
Hanne Trautner-Kromann
}

København

\section{Det historisk modsætningsforhold mellem jøder og kristne}

Fra kristendommens første århundreder har der bestået et modsætningsforhold mellem kristendommen og jødedommen. Det nære slægtskab mellem disse to religioner og det fælles grundlag i Den jødiske Bibel gav anledning til religiøse diskussioner mellem jøder og kristneog måske især til indre kristne overvejelser over dens stilling i forhold til den jødiske tro. Kristendommens krav på at være den ene sande religion for alle folkeslag gav desuden de kristne en missionsiver, som $\mathrm{i}$ høj grad var rettet mod jøderne. Allerede i Det nye Testamente spores en polemik mod jøderne, f.eks. i omtalen af farisæerne, ${ }^{3}$ og $\mathrm{i}$ de følgende århundreder fremkom der en række kristne skrifter med det formål at overbevise jøderne - og vel også de kristne selv-om den kristne tros sandhed. ${ }^{4}$ I løbet af det 11. årh. øgedes antallet af kristne polemiske skrifter mod jødedommen for at kulminere i det 12. årh. De kristne fortolkede Den jødiske Bibel kristologisk og læste tekster og begivenheder som udsagn og forudsigelser om Jesus, kristendommen og de kristne. Hertil kom i det 13. årh. forsøg på at fortolke Talmud og Midrash, der hidtil ikke havde været indraget $\mathrm{i}$ den religiøse debat, kristologisk og bruge passager herfra som bevis på kristendommens sandhed. Denne religiøse pression fra kirkens side for at omvende jøderne til kris- tendommen blev underst $\varnothing$ ttet af de verdslige myndigheder, som indskrænkede jødernes retssikkerhed og erhvervsmuligheder og tvang dem til at deltage i religiøse disputter med de kristne og til at påhøre omvendelsesprædikener. ${ }^{5}$ Denne pression blev kraftig i Frankrig i det 13. årh., men i Spanien først i det 14. årh.

Jøderne reagerede på alle disse former for pression ikke blot ved at forsvare jødisk tro og livsførelse, men også ved at angribe kristen tro og livsførelse. ${ }^{6}$ Jødiske polemiske tekster mod kristendommen kan således ses som en reaktion på en umiddelbart forudgående eller samtidig kristen pression. Dette er baggrunden for, at der blev skrevet et stort antal jødiske polemiske skrifter i Frankrig i det 13. årh. og i Spanien især i det 14. og 15. årh., men teksterne er ikke primært rettet mod de kristne.

2. Oversigt over forskning i jødisk polemik

Udforskningen af jødisk polemik mod kristendommen kom kun langsomt i gang midt i det forrige århundrede, men gik hurtigt i stå, muligvis som følge af den racistiske antisemitisme der voksede sig stærk i slutningen af det 19. 
årh. I 1880'erne beskrev forskere som Isidore $\mathrm{Loeb}^{7}$ og Zadoc Kahn ${ }^{8}$ en eller flere polemiske tekster og mente, at disse kunne belyse historiske forhold og relationerne mellem jøder og kristne, men de analyserede ikke teksterne og kommenterede dem næsten heller ikke. Adolf Posnanski udgav i 1904 et værk med jødiske fortolkninger af det omdiskuterede Shiloh-citat fra 1. M.B. kap. 49 vers 10 , og heri er der også en del polemisk materiale, men han hverken kommenterede eller analyserede det. ${ }^{9}$ I begyndelsen af 1900-tallet blev et par middelalderlige værker med polemiske passager udgivet, men ikke analyseret, ${ }^{10}$ og i 1928 udgav J.D. Eisenstein en lang række polemiske værker på hebraisk med en kort indledning om den historiske baggrund, men igen uden nogen egentlig analyse af teksterne. Desuden var teksterne filologisk utilstrækkelige eller fyldt med fejl. ${ }^{11}$

Først i 1935 med Efraim Urbachs artikel Études sur la littérature polémique au moyen$\hat{a}$ ge kom der en egentlig analyse og kommentering af jødisk polemik. ${ }^{12}$ Urbach har den tese, at de tidligste af teksterne fra det 12. og begyndelsen af det 13. århundrede refererer faktisk stedfundne disputter, medens han anser den senere polemik for at være eksempler på svar til brug for $\mathrm{j} \emptyset$ der $\mathrm{i}$ diskussioner med de kristne, altså en slags lærebøger. Under 2. verdenskrig gik polemikforskningen igen i stå, men i 1950'erne udkom enkelte værker om jødisk polemik af forskere som Hans Joachim Schoeps, ${ }^{13}$ Morris Goldstein ${ }^{14}$ og Oliver Shaw Rankin, ${ }^{15}$ som dog kun byggede på ganske få jødiske tekster fra middelalderen. Bernhard Blumenkranz' forskning er dybtgående, men har tyngdepunktet før år 1200 og tangerer herved kun lige den her valgte periode. ${ }^{16}$

Yitzhak Baers værk $A$ History of the Jews in Christian Spain ${ }^{17}$ i 2 bind indeholder mange beskrivelser af polemiske forfattere og tekster i relation til de historiske forhold, og Salo W. Baron giver en ofte analyserende fremstilling of disputter og polemik i værket $A$ Social and Religious History of the Jews. ${ }^{18}$ Først Judah Rosenthals store bibliografi i 1960 Anti-Christian Polemics from its Beginnings to the End of the 18th Century fører til et egentligt gennembrud for polemikforskningen. ${ }^{19}$ Siden Rosenthals bibliografi er der blevet udgivet mange artikler og monografier om polemiske tekster i middelalderen, ligesom der er blevet trykt en række kildeskrifter, heraf nogle i tekstkritiske udgaver.

Forskerne kan groft inddeles i tre kategorier efter deres grundholdning til det polemiske materiale:

Som tidigere er der stadig nogle der nøjes med at publicere de polemiske tekster, men de analyserer ikke indholdet $\mathrm{i}$ dem.

Den anden gruppe, som er langt den største, opfatter teksterne som et egentligt forsvar for jødedommen mod kristne angreb. Forsvaret kan eventuelt have form som en lærebog $i$ angreb på kristendommen. Disse forskere sætter værkerne ind i deres historiske kontekst og til en vis grad også i relation til andre polemiske værker.

Den tredje gruppe omfatter de relativt få forskere, som også er opmærksomme på aspektet: opmuntring af jøder og bestyrkelse af deres tro. Forskere som Rosenthal, ${ }^{20}$ Berger $^{21}$ og Talmage ${ }^{22}$ antyder ganske vist dette interne formål, men Chazan ${ }^{23}$ og især Fraenkel-Goldschmidt ${ }^{24}$ understreger det kraftigere, dog kun vedrørende enkelte tekster. Det er denne sidstnævnte synsvinkel-den interne opmuntring - der skal argumenteres for i det følgende.

\section{Synsvinkel ved analyser af udvalgte hebraiske tekster fra Spanien}

Som anført anlægger ingen af forskerne af jødisk polemik systematisk den overordnede synsvinkel på jødiske polemiske tekster, som jeg har argumenteret for i min afhandling, nemlig:

for det første: at formålet med jødisk polemik i middelalderen primært er at bestyrke jøderne i fastholdelsen af deres religion på trods af den stadig stigende kristne pression;

for det andet: at midlet til at bestyrke jøderne i deres tro er at forsyne dem med argumenter imod de kristnes påstande.

Disse argumenter kan vedrøre de kristnes fortolkning af de jødiske skrifter, eller være en 
tilbagevisning af de kristnes kritik af jøderne, men de kan også være angreb på de kristne selv og på deres hellige skrifter og dogmer. Her har jeg valgt at belyse jødernes kritik af de kristne dogmer, og den netop anførte synsvinkel: formål og middel vil blive anvendt med henblik på fortolkningen af de følgende 3 tekstuddrag.

3.1. Den første tekst, Sefer haVikkuach, ${ }^{25}$ er skrevet af Rabbi Moshe ben Nachman, RAMBAN, et par år efter hans tvungne deltagelse $\mathrm{i}$ disputten i Barcelona i 1263, som fandt sted $i$ overværelse af kongen af Aragonien og mange højtstående gejstlige. De kristnes formål med disputten var at overbevise Ramban om, at også det jødiske værk TALMUD indeholdt beviser på, at messias allerede var kommet, og at Jesus dermed var messias. De mente, at hvis RAMBAN, der var den førende rabbiner og jødiske lærde i Spanien, kunne overbevises om, at Jesus ifølge TALMUD var messias, så ville både han og alle andre jøder frivilligt gå over til den kristne tro. RAMBAN afviser imidlertid totalt, at TALMUD kan bruges som bevis for kristendommens sandhed, og han påpèger, at den jødiske og den kristne opfattelse af messias' natur er i fuldstændig modstrid med hinanden. Ramban taler direkte til kongen i du-form og siger (Ramban 1963: $310 \mathrm{f}$.):

\section{אבל עיקר הדיז והמחלוקת שבין היהודים וביז הצוצרים הזא במה שאתם}

אומרים בעיקר האלהות דבר מר מאד. ואתה אדוננו המלך נוצרי בן נוצרי [ובן נוצרית]

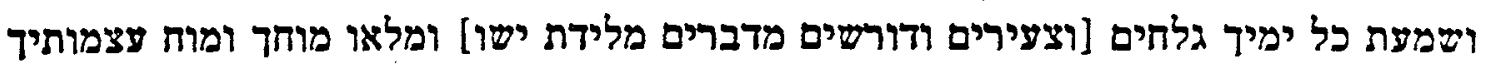

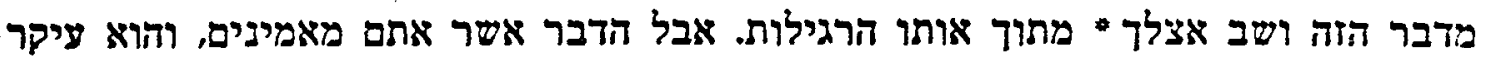

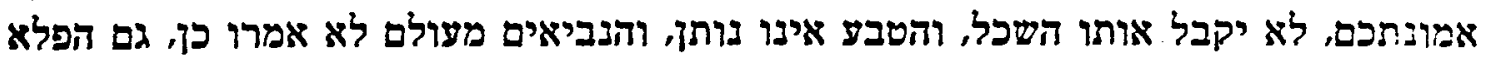

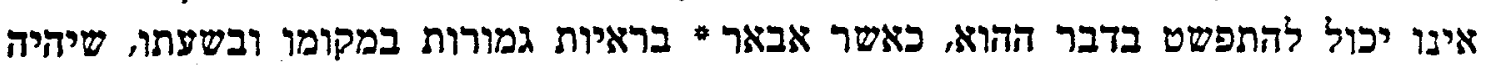

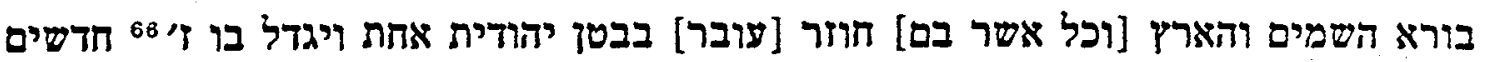

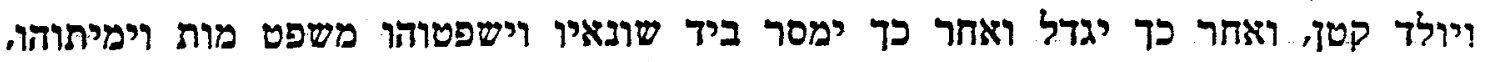

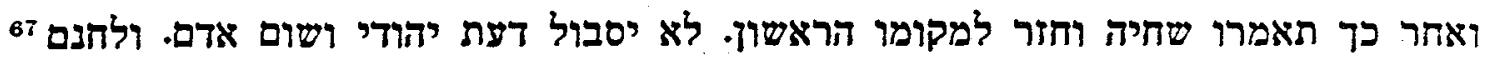

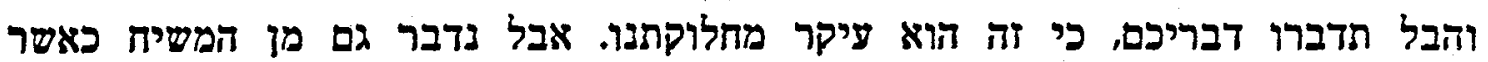

Men den virkelige strid og uenighed mellem jøderne og de kristne vedrører det I siger om essensen af Gud, som er en overordentlig afskyelig doktrin. Men du, vor herre konge, er en kristen og søn af en kristen, og du har hele dit liv lyttet til præster, som har fyldt din hjerne og dine knoglers marv med denne doktrin, og den kommer til dig på grund af denne vane. Men den doktrin, som I tror på, og den er grundlaget for jeres tro, kan fornuften ikke godtage, og naturen tillader den ikke, og profeterne har aldrig sagt således. Ejheller kan et mirakel udstrække sig til denne doktrin, således som jeg vil forklare med fuldgyldige beviser på rette sted og tid, så at Skaberen af himlen og jorden skulle søge ind $\mathrm{i}$ en $\mathrm{j} \emptyset$ dindes mave og vokse der $\mathrm{i}$
9 måneder og blive født som et spædbarn og derefter vokse op og så blive overladt til sine fjender, som dømte ham til døden og dræbte ham; og bagefter hævder I, at han blev levende og vendte tilbage til sit oprindelige sted. En jødes eller noget andet menneskes forstand kan ikke acceptere dette. Og I taler fuldstændig forgæves, for dette er roden til vor uenighed.

RAMBAN hævder således, at den kristne doktrin om inkarnation er fuldstændig ulogisk, imod naturens love og uacceptabel for alle andre end de kristne, der er vænnet til denne doktrin. Derfor er alle de kristnes omvendelsesforsøg af jøderne forgæves, ligeledes alle religiøse diskussioner, idet den kristne og den 
jødiske lære ikke kan forliges.

RAMBAN benytter midlet: kritik af dogmet om inkarnationslæren, og han argumenterer så udførligt og detaljeret imod denne lære, at det viser hans virkelige formal: at overbevise jøderne om, at inkarnationslæren er falsk og umulig, og at ingen jøde kan acceptere en sådan tro.

3.2. Den anden tekst er fra Profiat Durans ironiske brev Al tehi keAvotekha, ${ }^{26}$ Vær ikke som dine Forfædre, som han skrev efter de voldsomme forfølgelser af jøderne $i$ hele Spanien i 1391. Mange menigheder blev udslettet som følge af massakrer og tvangsdåb, og medens nogle af de tvangsdøbte søgte at vende tilbage til jødedommen efter at forfølgelserne var slut, var andre blevet overbeviste kristne. Forfatteren og lægen Profiat Duran skrev netop sit brev til en tvangsd $\varnothing$ bt ven, der ville forblive kristen. Duran ironiserer over den kristne tro, blandt andet over treenighedsdogmet, og han henvender sig direkte til den forhenværende jøde og siger (Duran 1981: 74):

\section{אל תהי כאבותיך אשר האמינו באלוה האחדות הפשוטה לבד ושללו ממנו הריבוי לגמרי}

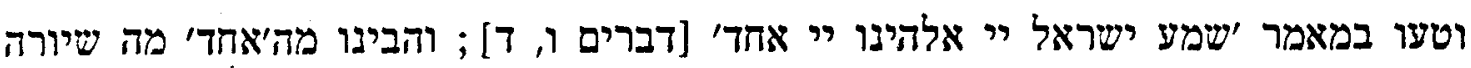

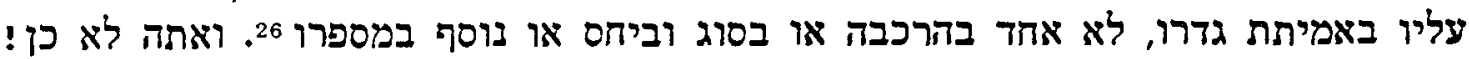

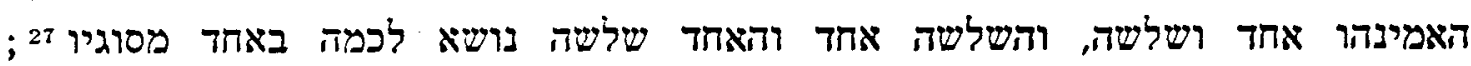

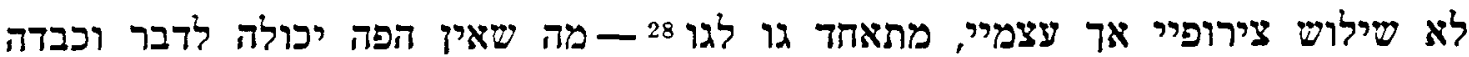
האוזן משמוע 29 ; אילוש להוסי אריף עצמיי, מתיו ואין לגרוע לגוע

Vær ikke som dine forfædre, som kun troede på én Guds totale enhed og fuldstændig benægtede nogen som helst flerhed heri og misforstod sentensen (5. M.B. 6, 4): Hør, Israel! Herren er vor Gud, Herren er én; og ved "én" forstod de det som det betyder i den sande definition, ikke én med inkludering af kategori eller relation eller udvidelse af antallet. Men ikke du! Du skal tro, at en er tre og de tre er en, og at den ene indeholder tre til kvantitet $i$ en af dens kategorier; ikke en sammensat, men en egentlig trehed, der forener krop med krop-hvilket munden ikke kan udtale og øret er træt af at høre; der må ikke føjes noget til eller trækkes noget fra.

Duran modstiller således jødernes traditionelle opfattelse af Guds udelelige og totale enhed med de kristnes dogme om Guds enhed, som består af tre dele: faderen, sønnen og helligånden. Ifølge Duran kunne Gud godt tillægges attributter, som udtryk for Hans relation til verden, men disse attributter kunne ikke udsige noget om Guds egen essens. De kristne derimod hævdede, at treenigheden ikke blot var attributter, men gud selv, og derfor var dette kristne dogme uacceptabelt for jøderne og i strid med deres opfattelse af logik. Duran citerer forbudet fra 5. M.B. kap. 13 vers 1 mod at føje noget til loven eller trække noget fra, men han undlader at citere fortsættelsen, som er en lang omtale af falske profeter og afgudsdyrkelse, som fordømmes på det skarpeste.

En sådan undladelse er en typisk jødisk polemisk fremgangsmåde, hvorved kritikken bliver indirekte eller underforstået. Det ville være for farligt for Duran at fordømme de kristne direkte, men enhver jøde der var bibelkyndig ville forstå hentydningen og selv kunne færdiggøre citatet. Duran benytter således ironien som middel til at fremhæve rigtigheden af den jødiske tro i modsætning til den falske kristne lære, der endda strider imod Moseloven. Formålet med teksten er klart at opmuntre jøderne til fastholdelse af deres religion $i$ en tid med stor undertrykkelse og deraf følgende frafald fra jødedommen.

3.3. Den tredje tekst er skrevet af rabbineren og prædikanten Josef Albo. Han forfattede 
sit filosofisk-teologiske værk Sefer halkkarim, ${ }^{27}$ Princippernes Bog, i 1425, og hans formål med værket var at give jøderne en fremstilling af principperne i Moseloven, som kunne tjene som vejledning i den rette jødiske tro. I værket kommer Albo også ind på den kristne lære, og i et af kapitlerne refererer han en disput med en kristen lærd, som blandt andet kritiserer den jødiske religion på grund af de bibelske offerlove. Den kristne hævder, at dyreofre er urene, hvorimod de kristnes ofre, sakramentets brød og vin, er rene. Albo forklarer først formålet med og helligheden af de jødiske ofre, som har en højere betydning end de kristne mener, hvorefter han angriber de kristnes opfattelse af nadveren som et offer til Gud (Albo 1929 III: 231-232):

ועור כי מה שאומרים מקרבן הלחם והיין שהוא קרבןנקיא אין הדבר כן, כי הלחם והיין אינם קרבן אלהיהם אבל לפי מה שהם אומרים הוא גוף

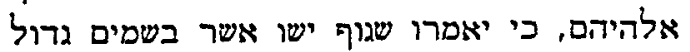

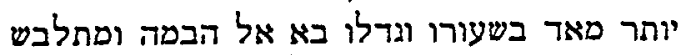

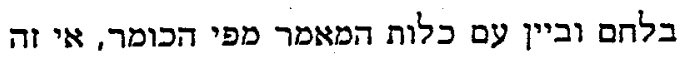
5

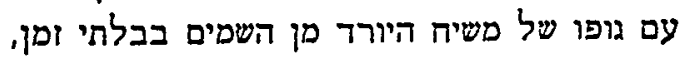

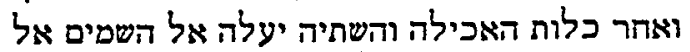

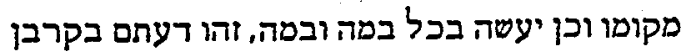

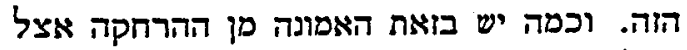

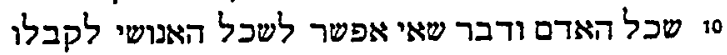

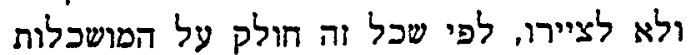
הראשונות ועל המוחשות. לפי לירל

Desuden er det de siger om ofring af brød og vin, at det er et rent offer, slet ikke rigtigt, thi brødet og vinen er ikke et offer til Gud, men efter hvad de selv siger, er det deres guds legeme, for de siger, at Jesu legeme, som er i himlen og er overordentlig stor i udstrækning og storhed, kommer til alteret og iklæder sig brødet og vinen, så snart præsten er færdig med at sige ordene, uanset hvem præsten er, om han er retskaffen eller ond, og det hele bliver til ét legeme sammen med messias' legeme, som stiger ned fra himlen på ingen tid. Og når brødet og vinen er fortæret, stiger han op til himlen til sin plads, og dette sker på hvert eneste alter. Dette er deres opfattelse af dette offer. Og hvor fremmed er ikke denne tro for menneskets intellekt, for det er en umulig ting for den menneskelige intelligens at acceptere eller forestille sig, eftersom en sådan opfattelse er i modstrid med de første grundsætninger og det der kan sanses.

De kristnes tro på transsubstantiation var et tilbagevendende angrebspunkt for jøderne, og Albo afviser, at dette dogme skulle kunne sidestilles med de gamle jødiske ofre og dermed have basis i Den jødiske Bibel. Indirekte anklager han de kristne for at fortære deres gud og iøvrigt være ulogiske og uintelligente. Albo benytter således kritikken af dette dogme som et middel til at overbevise jøderne om, at den kristne lære var falsk, medens den jødiske opfattelse var $\mathrm{i}$ overensstemmelse med Moseloven. Herved opnår han sit formail: at opmuntre jøderne til at holde fast ved deres egen religion.

\section{Sammenligning med hebraiske tekster fra Frankrig}

En analyse af 57 udsnit fra polemiske tekster mod de kristne fra Spanien og Frankrig ${ }^{1}$ viser samme mønster: det primære formål er at bestyrke jøderne $\mathrm{i}$ fastholdelsen af deres tro, og midlet hertil er at komme med argumenter af forskellig art-saglige, ironiske eller latterliggørende-imod den kristne lære.

I det følgende skal begrundes, hvorfor jeg mener, at det primære formål med de polemiske tekster mod kristendommen i middelalderen er opmuntring til fastholdelse af den jødiske tro, selv om andre forskere opfatter nogle af teksterne som lærebøger i polemik mod de kristne. ${ }^{28}$

For det første: Argumenterne mod den kristne lære og de kristne er ofte slet ikke umiddelbart brugbare i en religionsdisput, fordi de er uforståelige for de kristne, der ikke har samme religiøse og vidensmæssige baggrund som jøderne. Derfor skal argumenterne først bearbejdes og omformes af jøder for at kunne anvendes $i$ 
diskussioner med de kristne.

For det andet forudsætter alle de polemiske tekster en viden om hebraisk sprogbrug og jødisk tekstfortolkning, som de kristne almindeligvis slet ikke havde. Mange passager er skrevet på en indforstået måde, hvor meget kun er antydet eller udtrykkes indirekte. Således kan de jødiske polemikere spille på jødernes generelle kendskab til Den jødiske Bibel, hvorved de kan indflette tilsyneladende "uskyldige" bibelpassager $\mathrm{i}$ teksten og påregne, at læseren selv kender konteksten, som hermed bliver benyttet kritisk eller krænkende mod de kristne. Dette var for eksempel tilfældet i citatet fra Profiat Duran.

For det tredje tilhører alle teksterne de persuasive teksttyper ${ }^{29}$ propaganda og mission, der benytter sig af retoriske stiltræk og appellative virkemidler, for eksempel skjulte eller antydende citater, og som forudsætter, at modtagerne har et indgående kendskab til jødedom.

For det fjerde er teksterne skrevet på hebraisk, og målgruppen må derfor være jøder, idet kun de færreste kristne forstod dette sprog. Hvis teksterne var beregnet for kristne, ville det have været mere hensigtsmæssigt at skrive dem på latin eller det lokale folkesprog, som jøderne også brugte.

Der er således ikke grund til at antage, at teksterne henvender sig til kristne læsere for direkte at argumentere imod dem, eller at det primære formål med de polemiske tekster er at være lærebøger til brug ved faktiske disputter med de kristne. Selv om det er et gennemgående fællestræk for teksterne, at de tager udgangspunkt $i$ eller afspejler stedfundne religiøse diskussioner, så fremgår det tydeligt, at det primære formål med teksterne er at overbevise jøderne om, at den kristne tro er falsk og den jødiske sand.

Midlerne til at opnå formålet: at bestyrke jøderne i deres tro var at forsyne dem med $a r$ gumenter imod den kristne lære og de kristne, og disse argumenter kan inddeles i tre grupper:

1. argumenter imod de kristne dogmer ${ }^{30}$

2. argumenter imod de kristnes kristologiske skriftfortolkning ${ }^{31}$

3. argumenter imod de kristnes slette livsførel$\mathrm{se}^{32}$
Både teksterne fra Frankrig og Spanien kendetegnes ved, at de kritiserer de kristne dogmer, men i de spanske tekster argumenteres der i højere grad ud fra filosofiske systemer end i Frankrig, hvor dogmerne blot kritiseres for at være fornuftsstridige eller endog noget vrøvl.

Også afvisningen af de kristnes allegoriske og kristologiske skriftfortolkning følger de samme baner, men teksterne fra Spanien adskiller sig fra teksterne fra Frankrig derved, at de kristne siden Barcelonadisputten i 1263 ikke blot fortolker Den jødiske Bibel, men også dele af Talmud og Midrash som bevis på kristendommens sandhed. Derimod havde de kristne under den såkaldte Pariserdisput i 1240 tværtimod anklaget Talmud for at håne den kristne lære.

Det tredje argument med angreb på de kristnes ondskab og umoral er derimod forskelligt udformede i teksterne fra Frankrig og Spanien. De franske fremkommer ganske vist med anklager mod de kristne, men fokuserer mere på jødernes egen høje moral. De spanske tekster anklager også de kristne for umoral og for at forfølge og undertrykke jøderne, men fremhæver ikke jødisk moral.

I Frankrig udgjorde rentetagning et særligt problem, idet et stort antal af jøderne levede af pengeudlån, hvorimod dette emne kun sjældent blev debatteret i Spanien, hvor flertallet levede af mange forskellige erhverv. Forskellene i erhvervsstrukturen afspejler sig således tydeligt $\mathrm{i}$ teksterne. En anden forskel på de to lande er de franske jøders stærke religiøsitet og selvfølelse, specielt blandt de nordfranske/ ashkenaziske jøder, idet de fremhæver deres høje moral gang på gang og stiller den i modsætning til de kristnes umoral. Denne selvfølelse og fremhævelse af egen moral findes ikke i teksterne fra Spanien, selv om de sefardiske jøder også kritiserer de kristnes umoral. Årsagen til denne forskel må antages at være, at jøderne i Frankrig var en lille og stort set den eneste minoritet $i$ forhold til den franske befolkning, og at det religiøse og erhvervsmæssige pres af politiske og $\varnothing$ konomiske grunde satte tidligere ind her, ligesom jøderne hurtigt blev overflødige i den franske erhvervsstruktur. Disse faktorer kan have medført en større grad af 
samhørighed både religiøst og socialt, således at de bedre kunne modstå det kristne pres.

I Spanien var jøderne en langt større minoritet og ikke den eneste, og der havde $\mathrm{i}$ adskillige århundreder været behov for deres varierede erhvervsindsats, ikke mindst $i$ forbindelse med reconquistaen. Fra islamisk tid havde der heller ikke blandt de sefardiske jøder været den tradition for kulturel afsondrethed, som prægede de ashkenaziske, tværtimod var ledende jødiske kredse stærkt påvirket af filosofiske og videnskabelige ideer, som i mange tilfælde ikke virkede fremmende for religiøsiteten. Endelig blev grundlaget for en jødisk tilværelse flere gange på dramatisk og spektakulær vis angrebet under religionsforfølgelser og offentlige disputter samtidig med, at det kristne samfund udøvede et vedvarende religiøst, socialt, økonomisk og civilretsligt pres på jøderne for at få dem til at konvertere. Dette langvarige pres over flere hundrede år med sporadiske voldsomme overgreb kunne være årsagen til, at jøderne klager over mange former for forfølgelse af dem, og at de kristne i flere tekster endog anklages for at ville dræbe jøderne.

\section{Konklusion og perspektivering}

Gennemgangen af de polemiske teksteksempler har vist, at det er nødvendigt at skelne mellem formålet med teksterne og de midler der benyttes til at opnå formålet. Hvis der ikke skelnes mellem dem, kan det resultere i utilstrækkelige fortolkninger af teksterne. Når man for eksempel gør midlet til formålet og opfatter en tekst som en lærebog i polemik mod de kristne, så forveksler man midlet med formålet, og fortolkningen af teksten bliver mangelfuld. Da de jødiske polemiske tekster er en reaktion på kristen pression er det desuden nødvendigt at inddrage de historiske forhold for at kunne belyse teksterne fuldt ud.

Selv om udviklingen i Frankrig og Spanien ikke helt følger det samme mønster, er både midler og slutresultat de samme. Den religiøse pression tager gradvis til og sideløbende hermed en politisk, økonomisk og fysisk pres- sion, men hastigheden $i$ udviklingen af pressionen kan siges at være forskellig, ligesom presset ikke er stigende i lige linie gennem hele perioden, men i en takket linie, afhængig af de aktuelle historiske forhold og begivenheder. Men det er et fælles træk for teksterne, at selv få år før den endelige katastrofe er der $i$ de her unders $\varnothing$ gte tekster ikke udtrykt nogen formodninger om de forestående begivenheder: udslettelsen af jødedommen og de jødiske menigheder i de kristnede franske og spanske samfund ved fordrivelsen af jøderne fra Frankrig i 1306 og fra Spanien i 1492.

Det samlede forskningsresultat af de undersøgte tekster synes at tillade den generalisering der går ud på, at en jødisk minoritet vil besvare en pression af religiøs, økonomisk og social art med et modsvar, uanset period og sted, med'henblik på at bestyrke jøderne i deres tro, idet enhver form for pression vil blive opfattet som et spørgsmål om overlevelse som religiøs minoritet. Den jødiske religions udøvere synes at udgøre en stabil og konstant faktor, der selv under særdeles ugunstige og livstruende vilkår vil have det mål at opmuntre jøderne til fastholdelse af deres tro. Reaktionen på pressionen kan tage forskellige former og benytter forskellige midler, men formålet synes at være det samme: bevarelse af jødedommen.

Ud fra denne generaliserende formålsdefinition kunne andre og langt flere end de her undersøgte tekster og teksttyper formentlig analyseres efter samme metode med nye eller hidtil upåagtede resultater som følge, som kunne have interesse for religionsforskere, teologer, historikere og filologer. Men der savnes i høj grad tekstudgaver, som er tekstkritisk forsvarlige, ligesom de bør udgives $\mathrm{i}$ oversættelse til et vestligt sprog for at gøre dem tilgængelige for alle forskere, og ikke kun for judaister. Det jødiske polemiske materiale $\mathrm{i}$ de forskellige teksttyper ${ }^{33}$ kunne endvidere sammenholdes med tilsvarende kristne polemiske tekster mod jøderne. En sådan sammenligning ville formentlig kaste nyt lys over relationerne mellem jøder og kristne i middelalderens Europa, og dermed tydeligere belyse baggrunden for de senere århundreders jødefjendtlighed, jødehad og antisemitisme. 
Udforskningen af hebraisksprogede kildetekster fra middelalderen er desværre endnu et ret uopdyrket område indenfor judaistikken. Forskningsresultaterne heraf ville ikke blot tjene judaistikken og bidrage med nye oplysninger om forholdene mellem jødedom og kristendom, og også mellem jødedom og islam, men ville også yde bidrag til det interdisciplinære samarbejde mellem religionsvidenskab, teologi, historie, filologi og litteraturvidenskab.

\section{NOTER}

1. Forelæsningen bygger på en afhandling med titlen: "Jødisk polemik mod kristendommen og de kristne i Frankrig og Spanien fra 11001500". Den er på 300 sider plus 34 sider med de hebraiske kildetekster, som omfatter 57 tekstuddrag skrevet af 17 forskellige forfattere fra Frankrig og Spanien. Afhandlingen blev i september 1988 indleveret til Københavns Universitet med henblik på bedømmelse som doktordisputats.

2. Da jeg havde publiceret en artikel i Nordisk Judaistik om jødiske polemiske tekster fra Frankrig, jvf. Trautner-Kromann 1986, udvalgte jeg tre tekster fra Spanien till prøveforelæsningen $i$ Lund.

3. Se f.eks. Lukas $18 \mathrm{om}$ farisæeren og tolderen.

4. Jvf. Williams 1935.

5. Jvf. Trautner-Kromann 1986.

6. Jvf. Trautner-Kromann 1984.

7. Loeb 1889.

8. Kahn $1880 \mathrm{f}$.

9. Posnanski 1904.

10. Pulgar 1906 og Albo 1929.

11. Eisenstein 1928.

12. Urbach 1935.

13. Schoeps 1961.

14. Goldstein 1950.

15. Rankin 1956.

16. Blumenkranz 1977.

17. Baer 1978.

18. Baron $1952 \mathrm{ff}$.

19. Rosenthal 1960-61.

20. Official 1970.

21. Berger 1979.
22. Talmage 1975:1 og 1985:380 n. 3 .

23. Chazan 1985.

24. Bivach 1978.

25. Ramban 1963.

26. Duran 1981.

27. Albo 1929.

28. Jvf. artiklens hovedpunkt 2.

29. Reiss 1976: 43-55.

30. Jvf. artiklens hovedpunkt 3.

31. Et kendt eksempel er Shiloh-citatet, jvf. Posnanski 1904 og Trautner-Kromann 1986.

32. I min afhandling er der mange eksempler herpå.

33. Jvf. Trautner-Kromann 1984.

\section{LITTERATURLISTE}

REJ $=$ Revue des Études Juives. Vol. 1-, 1880-. Paris.

Albo, Joseph, 1929, Sefer ha-'Ikkarim. Book of Principles. I. Husik (ed.). Philadelphia.

Baer, Yitzhak, 1978, A History of the Jews in Christian Spain. Vol. 1-2. Philadelphia.

Baron, S.W., 1952ff, A Social and Religious History of the Jews. Vol. 9, 10 og 11. New York.

Berger, D. (ed.), 1979, The Jewish-Christian Debate in the High Middle Ages. A Critical edition of the Nizzahon Vetus. Philadelphia. Bivach, Abraham, 1978, Derekh E'muna. Fraenkel-Goldschmidt, Chava (ed.). Jerusalem.

Blumenkranz, B., 1977, Juifs et Chrétiens Patristique et Moyen Age. (Reprints). London.

Chazan, R., 1985, Polemical Themes in the Milhemet Mizvah. Les Juifs au regard de l'histoire. Mélanges en l'honneur de Bernhard Blumenkranz. Ed. G. Dahan, p. 169-184.

Duran, Profiat, 1981, The Polemical Writings of Profiat Duran. Talmage, F. (ed.). "Kuntresim". Texts and Studies. 55. Jerusalem.

Eisenstein, J.D., 1928, Otsar Wikuchim. A Collection of Polemics and Disputations. New York.

Goldstein, M., 1950, Jesus in the Jewish Tradition. New York. 
Kahn, Z., 1880-1882, Étude sur le livre de Joseph le Zélateur. REJ 1:222-246; 3:1-38.

Loeb, I., 1889, Polémistes Chrétiens et Juifs en France et en Espagne. REJ 18:43-70; 219242.

Official, Josef, 1970, Sepher Joseph Hamekane. Rosenthal. J. (ed.). Jerusalem.

Posnanski, A., 1904, Schiloh. Ein Beitrag zur Geschichte der Messiaslehre. Leipzig.

Pulgar, I., 1906, The Support of Faith. Belasco, G.S. (ed.). London.

Ramban, 1963, Kitvei Rabbenu Moshe ben

Nachman. Vol. 1. Chavel, C.B. (ed.). Jerusalem.

Rankin, O.S., 1956, Jewish Religious Polemic of early and later centuries. Edinburgh Reiss, K., 1976, Texttyp und Übersetzungsmethode. Der operative Text. Kronberg.

Rosenthal, J., 1960-61, Anti-Christian Polemics from its Beginnings to the End of 18th Century. Ben-Menachem, N., Y. Raphael (ed.) Aresheth. An Annual of Hebrew Booklore. $2: 130-179 ; 3: 433-439$.
Schoeps, H.J., 1961, Jüdisch-christliches Religionsgespräch in neunzehn Jahrhunderten. München.

Talmage, F.E. (ed.), 1975, Disputations and Dialogue. Readings in the Jewish-Christian Encounter. New York.

Talmage, F., 1985, Trauma at Tortosa: The Testimony of Abraham Rimoch. Medieval Studies 47:379-415.

Trautner-Kromann, H., 1984, Sources of Jewish Polemics against Christianity in the Late Middle Ages. Temenos. Studies in Comparative Religion. 20:52-65.

Trautner-Kromann, H., 1986, Jewish Polemics against Christianity and the Christians in Northern and Southern France from 1100 to 1300. Nordisk judaistik/Scandinavian Jewish Studies. 7:71-83.

Urbach, E.E., 1935, Études sur la littérature polémique au moyen-âge. REJ 100:49-77.

Williams, A.L., 1935, Adversus Judaeos. A Bird's Eye View of Christian Apologiae until the Renaissance. Cambridge.

Die jüdische Polemik gegen das Christentum und die Christen in Frankreich und Spanien 1100-1500

\section{Zusammenfassung der Hauptergebnisse}

Die Habilitationsschrift enthält 5 Kapitel ( 300 S.) sowie einen Anhang (34 S.) mit den analysierten Textausschnitten aus den hebräischen Quellenschriften, die als empirische Grundlage für die Beschreibung und Erklärung der sogenannten jüdischen Polemik gegen das Christentum in Frankreich und Spanien zwischen dem ersten Kreuzzug (1096) und der Vertreibung der Juden aus Spanien (1492) dienen.

Im 1. Kapitel (S. 1-33) werden die Voraussetzungen für die Textinterpretation (Zielsetzung, Abgrenzung, Quellen- und Themenwahl, Analyseverfahren, Hypothesen und Stand der Forschung) dargelegt. Im 2. Kapitel (S. 3467) wird in großen Zügen die Geschichte der Juden in Frankreich und Spanien im Hinblick auf die zu analysierenden Texte umrissen. In den zwei folgenden Hauptkapiteln erfolgt die Analyse von 57 Textauszügen von 17 Autoren, und zwar nach einem Verfahren, bei dem erstens der Verfasser, sein Hintergrund und seine Intention mit dem Werk (AnlaB, Zielgruppe und Zweck), zweitens der Inhalt und die Form des Werkes, drittens der Forschungsstand in bezug auf das behandelte Werk und viertens die Textauswahl in Übersetzung (ins Dänische) und mit den relevanten Interpretationen beschrieben und erläutert werden. Im 3. Kapitel (S. 68-171) werden die Texte von Jacob ben Reuben, Josef Kimchi, Meïr von Narbonne, Sefer haBrit, Josef Official und Nizzachon Vetus abgehandelt und im 4. Kapitel (S. 172-271) die 
Texte der Barcelona-Disputation, von Solomon Adret, Bachia ben Asher, Isak Pulgar, Moses von Tordesillas, Shem Tov ibn Shaprut, Profiat Duran, der Tortosa-Disputation, Josef Albo, Chaim ibn Musa und Abraham Bibago. Im 5. Kapitel (S. 272-287) werden die Teilergebnisse aus den vorhergehenden Kapiteln in einem Vergleich aufeinander bezogen und in Relation zu den aufgestellten Hypothesen sowie abschließend zum derzeitigen Forschungsstand diskutiert.

Die Hauptergebnisse meiner Untersuchungen zu jüdischen polemischen Texten lassen sich folgendermaßen resümieren:

1. Meine Beschreibung und Erklärung der jüdischen polemischen Texte ist dier erste Versuch einer Gesamtdarstellung der Gründe für die jüdische Polemik in Frankreich und Spanien, und zwar in einer christlichen Umgebung und in einer Epoche, wo in einer entscheidenden Weise die Richtlinien für die spätere Geschichte des europäischen Judentums gestellt werden.

2. Bei den Textanalysen in der Gesamtdarstellung nehme ich systematisch auf die staats-, kirchen-, wirtschafts- und sozialgeschichtlichen Voraussetzungen der jüdischen Gemein den Bezug, wodurch die Texte in ihren historischen Kontext eingeordnet werden.

3. Meine drei Hypothesen werden durch die Textanalysen empirisch bestätigt:

3.1. Die jüdischen Texte polemischen Inhalts dienen dem Zweck, vor dem Hintergrund der christlichen Pression und Judenpolitik die Juden in ihrem Glauben zu ermutigen und zu bestärken. Dies wird anhand gewisser Eigenschaften der Texte (Verstehensvoraussetzungen, Interpretationsverfahren 'Peshat', Zitate, hebräische Sprache, u.a.) hinlänglich dokumentiert.

3.2. In den polemischen Texten bringen die jü- dischen Autoren Argumente gegen die christologischen Interpretationen der jüdischen Bibel, des Talmud und des Midrasch vor sowie gegen die christlich-theologischen Lehrsätze und die sozialen Anklagen gegen die Juden, und sie kritisieren die christliche Lebensweise und Unterdrückung der Juden; die Argumente und die Kritik in den Texten sind primär als Mittel zu betrachten, die der Ermutigung und Bestärkung der Juden in ihrem Glauben dienen und erst sekundär der religiösen Disputation mit den Christen.

3.3. Die Intensität in der Argumentation entspricht dem Grad (der Stärke) des christlichen Drucks auf die jüdischen Gemeinden: Je stärker der Druck auf die Juden, um so größer wird die Intensität der Argumentation in den jüdischen Texten. Diese Bedingtheit der Argumentationsintensität wird durch den Nachweis einer zeitlich vorangehenden oder gleichzeitigen und immer schärfer werdenden christlichen Pression auf die Juden in Nord- und Südfrankreich, in Aragonien und Kastilien bestätigt.

4. Mein zur Messung der Argumentationsintensitāt entwickeltes Verfahren stellt sich als praktisch anwendbar heraus: Die Meßskala baut auf den typischen Eigenschaften des polemischen Texttyps auf: Verteidigung und Angriff, Aufrichtigkeit versus Agitation.

5. Die Abhandlung enthält den neuesten Forschungsstand der jüdischen Polemik gegen das Christentum im Mittelalter sowie den Stand der Forschung in bezug auf das Werk der behandelten Autoren.

6. Die Forschungsergebnisse der Abhandlung dienen nicht nur der Judaistik und der Religionswissenschaft, sondern auch der Theologie, der Geschichtswissenschaft sowie der Philologie, insbesondere der Romanistik. Es handelt sich somit um einen Beitrag der Judaistik zu einer interdisziplinären Humanwissenschaft. 